\title{
Managing Stress During the Holidays ${ }^{1}$
}

\author{
Heidi Radunovich ${ }^{2}$
}

When we think of the holidays, we often think about family, togetherness, giving, and celebrating. While the holiday season should be a time of enjoyment, many events associated with the season can cause stress.

First, traveling during the winter season can be challenging. Traffic, crowded airports, flight delays, bad weather, and unhappy children can leave us feeling tired and stressed. During the holiday season, we often feel a need to spend more money than we can truly afford, spend more time on seasonal projects than what we have, and attend more events than we really should.

If we choose not to overextend ourselves, then we may feel guilty about our inability to do more. There are also family gatherings that could mean more togetherness than we are accustomed to and may entail many people grouped in small spaces for long periods of time.

Finally, with so much happening, little time is left to take care of ourselves, and our physical and emotional resources may become depleted. While some stress can help motivate us to be productive, too much stress can harm our health and reduce our enjoyment of the season.

\section{Ways to reduce and manage stress during the holiday season}

1. Plan Ahead and Get Organized: Many of us are so busy with our daily lives that we often don't feel as though we have time to plan ahead for the holidays. Taking care of things ahead of time, such as shopping for gifts and completing holiday cards, reduces your workload as you near the holidays, but many people don't have that option.

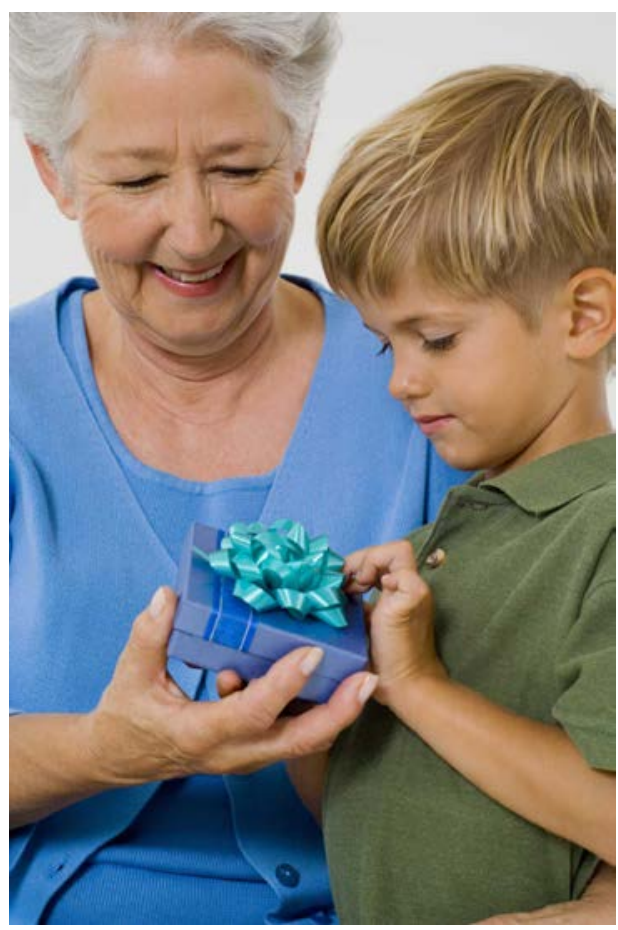

Figure 1. When we think of the holidays, we often think about family, togetherness, giving, and celebrating.

Credits: Pixiland

\section{Here are some ways to plan and get organized:}

- Even if your time for doing things in advance is limited, doing things a few minutes every day can help save time and reduce stress as the holidays approach. For example, having lists of what to buy and from where can prevent

1. This document is FCS5266, one of a series of the Department of Family, Youth and Community Sciences, UF/IFAS Extension. Original publication date November 2013. Visit the EDIS website at http://edis.ifas.ufl.edu.

2. Heidi Liss Radunovich, PhD, associate professor and human development specialist, Department of Family, Youth and Community Sciences, UF/IFAS Extension, Gainesville, FL 32611

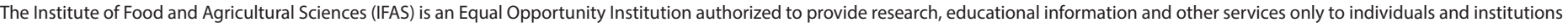
that function with non-discrimination with respect to race, creed, color, religion, age, disability, sex, sexual orientation, marital status, national origin, political opinions or affiliations. For more information on obtaining other UF/IFAS Extension publications, contact your county's UF/IFAS Extension office. 
multiple trips to the same store. Ultimately, taking a small amount of time now for planning can mean a big savings of time and stress in the future.

- Create lists of everything that needs to be done and bought, and create a schedule for the coming weeks to break down what you will do and when. It can be reassuring to see that you can manage all the work that needs to be done. If your schedule shows that you will be unable to finish everything in time, however, then skip the lower priority items on your list.

- Set a budget for your Christmas or holiday shopping, and plan how much you can spend for each person on your list. If you keep your spending limited to what you can afford, then you'll feel much less stressed later.

2. Set Realistic Expectations: Many of the images we see in movies and on TV can lead us to believe that a "perfect" holiday is realistic, and we may feel pressured to expect too much from ourselves, others, and the holiday itself. Rather than expecting your holiday to be "perfect," focus on the real meaning of the season. The ultimate goal is to enjoy quality time with people you care about.

\section{Here are some ways to keep your expectations in check:}

- Remember that life is full of things that go wrong, and anticipating perfection can lead to disappointment. Instead, expect that things won't be perfect, and view the problems that occur as an opportunity for a good story in the future.

- Remind yourself that it is ok if people don't always get along, if there are travel delays, or if the décor or food options aren't perfect.

- Focus on enjoying the positive moments as much as possible.

- Finally, take time to really think about what events you will attend (or host) and for how long, keeping in mind that sometimes less is more. Trying to attend every party or spend every possible moment with family might not always be the best plan, and it can leave you stressed and unhappy.

3. Take Care of Yourself: When we're feeling stressed we're much more likely to neglect our needs, but that is when we need to take care of ourselves the most. Making sure we eat healthy foods, exercise, get plenty of rest, and relax helps bolster us and renews our physical and emotional resources.

\section{Here are some ways to take care of yourself during the holidays:}

- Minimize indulgence. During the holidays, it is tempting to eat too much unhealthy food, drink too much alcohol, skip the exercise, and stay up too late. Although a little indulgence is ok, forgetting to take care of ourselves day after day leaves us physically and emotionally drained and unable to handle the stressors that come our way.

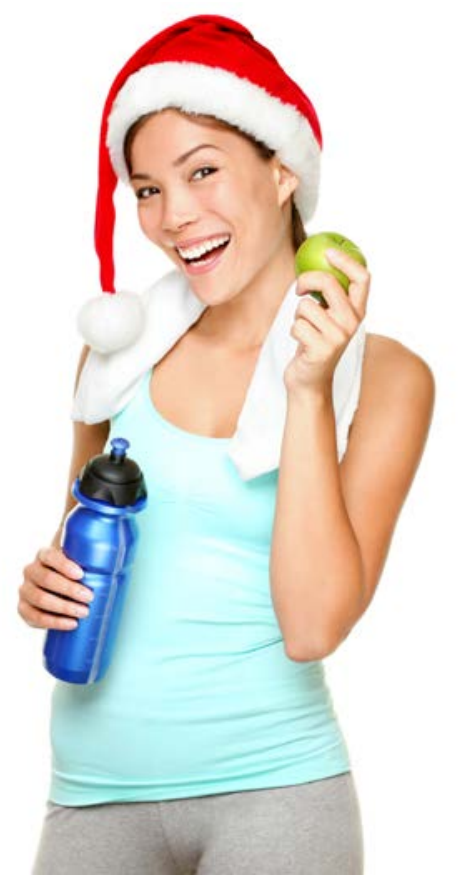

Figure 2. Making sure we eat healthy foods, exercise, get plenty of rest, and relax helps bolster us and renews our physical and emotional resources.

Credits: iStock

- If you enjoy trying all the different goodies at a party, make sure to just try a little bit of each. Focus on the healthier foods, such as vegetables, fruits, whole grains, and lean meats. You may also want to ask yourself if you are truly hungry or simply eating because food is available.

- If you are up late one night because of a party or giftwrapping session, make sure you go to bed early the next night.

- Increase your physical activity by walking after meals and taking stairs rather than elevators. Even walking in the mall can be a great source of exercise.

- Finally, take some time for yourself, even if it's only a few minutes while you're lying in bed in the morning. Hot baths or showers are relaxing, and reading can be a great escape. Some people also find meditation helpful. There may even be seasonal rituals that help you feel centered and relaxed, such as singing or lighting candles. 
Everyone is different, so you will need to figure out what activity provides a good way for you to take a break and decompress.

4. Manage Your Thoughts: The way you think about things can have a big impact on how stressful an event is for you. If you experience the same event as someone else, but you both have different thoughts about it, that can affect the way you feel. Once we are upset, it can be hard to think of things differently, but trying to take another perspective can help. For example, if a clerk at the airport is rude, rather than taking it personally, you could think that maybe this person is having a bad day. Finally, reframing the difficulties in a more positive way can help us have a sense of gratitude. For example, even though it's annoying to get a flat tire when you're getting ready to leave, it's better than it happening on the road or highway where it could cause an accident. Remember that the better you're able to manage your thoughts, the more you'll enjoy yourself.

\section{References}

American Psychological Association. (2012). Making the most of the holiday season. Psychology Help Center. Retrieved from http://www.apa.org/helpcenter/holidayseason.aspx

Elkin, A. (1999). Stress management for dummies. New York: Wiley Publishing, Inc.

Morgenstern, J. (2004). Time management from the inside out ( $\left.2^{\text {nd }} e d.\right)$. New York: Henry Holt and Company. 